\title{
2-2 ディジタル報道写真
}

一締め切り時間との戦い一

（新聞社におけるディジタルカメラ）

内藤 久 雄 ${ }^{\dagger}$

\section{1. ま え がき}

現場の映像をリアルタイムに映し出 すことができるテレビと異なり，新聞 写真には超えられない「締め切り」と いう難関がある．締め切り時間を 1 分 でもすぎれば，いくら特ダネでも紙面 に掲載できず，読者の目に触れるのは 12 時間近く遅れてしまう。

写真撮影と紙面に揭載されるまでの タイムラグをできるだけ短くしたいと いうのが, 新聞カメラマンの願いだっ た.わかりやすくいえば, 原稿締め切 りに限りなく近い時間の写真を紙面に 掲載したいというわけだ。特に大事件 やスポーツなどでは紙面で写真が主役 になるため，そのために新技術の導入 などさまざまな手段をとってきた。そ の中で登場した出稿までのレスポンス を極限まで短くできる「魔法の機械」 ディジタルカメラは, 我々にとって大 きな衝撃だった。

\section{2. ディジタルカメラ前史}

ディジタルカメラの登場までに新聞 写真がたどった速報性への挑戦と挫折 の歴史をまとめてみよう.

\section{1 スピードマグニ（図 1）}

手っ取り早く画像を手に入れよう と, キヤノンやニコンの一眼レフにポ ラロイドフィルム用アダプタを取り付 けたカメラである. 35 ミリフィルム 用に結像したイメージをポラロイドフ イルムの大きさに拡大するために, レ ンズやミラーを利用した光学系が間に 入っている. 現在, 一部の電子カメラ に見られる縮小光学系ならぬ拡大光学 系だ。このため, ISO 3200 のフル ムを使っても ISO 160 でしか撮影で きない.一眼レフの豊富なレンズが使

$\dagger$ 朝日新聞東京本社 編集局写真部

"Digital News Photo" by Hisao Naito

(Photo Section, Asahi Shimbun Publishing Co., Tokyo)

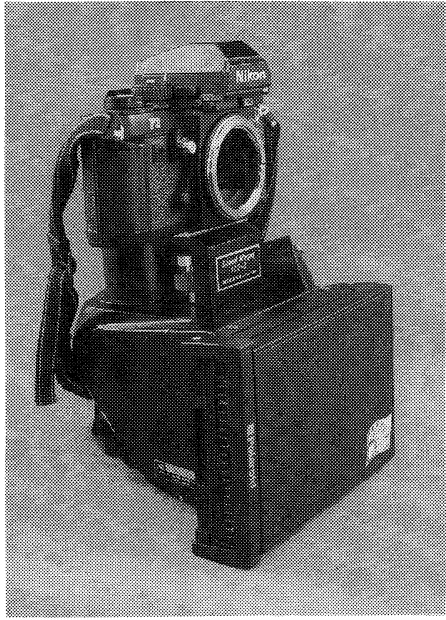

図 1 スピードマグニ (F 3 仕様)

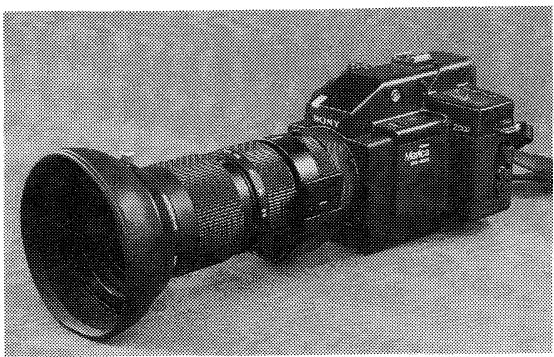

図 2 マビカ

用できるものの，使いにくいためスチ ルビデオカメラの登場で姿を消した。

\section{2 マビカ（図 2)}

ソニーが朝日新聞社向けに開発した スチルビデオカメラ.ロサンゼルス五 輪 (1984)，ソウル五輪 (1988)などで少 しだけ使われた。発表当時, 「銀塩写 真を駆逐するか」と騒がれたものの, NTSC 信号を採用したため画質が悪 く, 長時間かけてアナログ電送しなけ ればならなかったため, テスト使用に とどまり普及しなかった。 カメラとし ても使い勝手に問題があった。

\subsection{QV 1000 C（図 3)}

ニコンが開発したスチルビデオカメ ラ、報道向けに開発されたため，モノ クロ専用となった。専用電送機も同時 に発売された。モノクロに特化したた

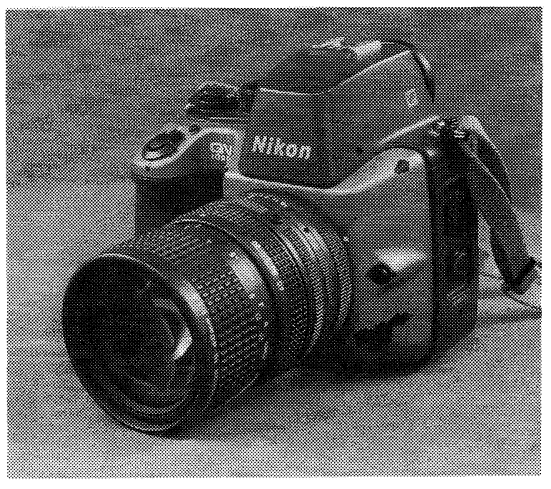

図 3 QV $1000 \mathrm{C}$

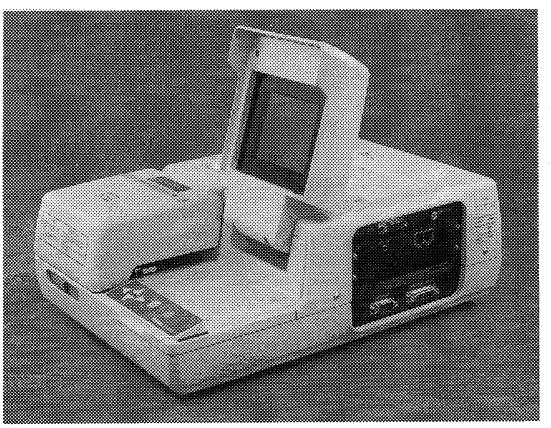

図 4 ダイレクト電送機（NT 3000）

め画質はそれなりに良かった。カメラ としてもかなり使いやすく,「SV」と 呼ばれて新聞各社の間で広く使われ t.

\section{4 ダイレクト電送機（図 4）}

ハッセルブラッド, AP 通信社, 二 コンなどが相次いで商品化した。印画 紙に焼き付けることなく，フィルムか ら直接電送することができるため, 出 張時の大きな福音となった。それまで は出張などには携帯用暗室（携帯とい つても大きなトランク 1 つにようやく 収まるくらいある）を持っていき，印 画紙に焼き付けるしかなかったから だ。これらの電送機はディジタル通信 に対応するなど，改良を重ねて地方支 局などでいまだに使われているもの の,フィルムスキャナとパソコン電送 


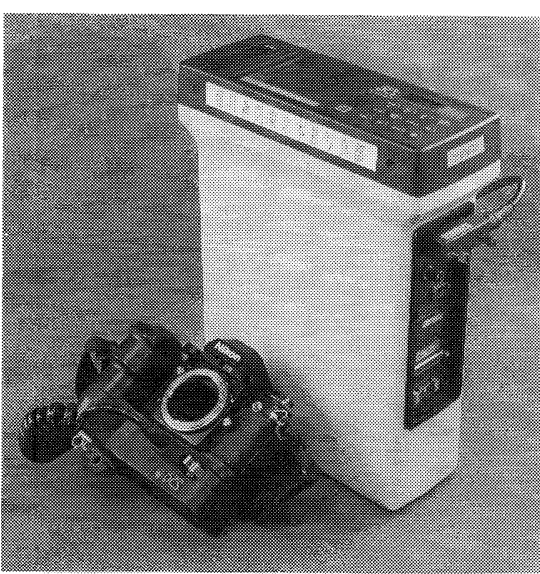

図５ＤCS(後方はハードディスクユニット)

機に置き換えられつつある。

\subsection{DCS（図 5)}

コダックが開発した最初のディジタ ルカメラ.ニコン F 3 ボディの裏ぶた にマトリクスタイプの CCD を装着し ている. スチルビデオカメラの画素数 の少ない悪い画像を見慣れた目には, 画質はきわめて高精細に見えた（今と なってはあたりまえの画質となった が）。ただし，画像を記録するのに巨 大な肩掛け式ハードディスクユニット が必要で, 機動性に欠けた。アルベー ルビル五輪などで使われたが，当時は デー夕伝送技術が進んでいなかったた め, 今から考えると非効率的な伝送方 法をとつていた．新世代のディジタル カメラが登場すると, ただちに使われ なくなった。

\section{3. 新聞社にとってのディジタ ルカメラシステム}

\section{1 ディジタルカメラの選択}

我々がディジタルカメラを選択する 場合の最低限の要求を重要度順に並べ てみよう。

（1）撮影しやすい. 通常のカメラ と同じような感じで使えないと いけない。連写機能は必須. AFもあった方がいい。

（2）画質, 発色がいい. 夜間な ぞ, 条件の悪い時でも, ある程 度の画質は欲しい。

（3）取り扱いが容易であること。 壞れやすいものはだめ。

（4）デー夕伝送が簡単なこと. 伝 送時間も短い方が望ましい.
（5）価格が安い！。

現在のところ，すべての条件を満た す機種は存在しない.いずれの機種も 100 万円を超える高価格で，一度導入 すれば簡単には別の機種に変更するこ とはできない。ディジタルカメラは発 展途上の技術で，待てば待つほどいい ものが登場するが，決断してある程度 の台数を導入しなければ役には立たな い。朝日新聞社では，E 2 Ns/DS 515 $\mathrm{A}$ (ニコン/富士写真フイルム) と EOS・DCS 3 (キヤノン）の 2 機種を 使用機種として選んだ. 現在, 東京写 真部では 10 台のディジタルカメラを 使っている。

\section{2 銀塩との使い分け}

ディジタルカメラは現状では画質等 の問題で，銀塩写真を置き換えるまで にはなっていない。

朝日新聞社では，ディジタルカメラ は速報性が必要な場合に使用してい る。午前中の事件など, 夕刊時間帯の 取材はディジタルカメラを利用するこ とが多い。朝刊締め切り間際も同様 だ。従来, 原稿輸送のオートバイで取 材フィルムを本社へ送っていたケース は，現在はほとんどディジタルカメラ の出番になる。特に事件では, いつ取 材できるかわからないこともあるた め, 結果的に使わなくても必ず持ち出 すようにしている。また，海外取材で も銀塩カメラとともに頻繁に活用して いる。

速報性以外でも，フィルムの現像， スキャン（朝日新聞ではもう印画紙へ の焼き付けは行っていない) などのプ
ロセスがす心゙て省略できるという点を 生かし, 大量の写真を出稿する必要が ある取材などへも使用を広げていきた いと考えている。

\section{4. 撮影から紙面化まで}

\section{1 撮 影}

東京本社では，E 2 Ns/DS 515 A を 主力ディジタルカメラとしている。電 送が簡単なため，一般的な取材全般に 適している。ホワイトバランスは，オ 一ト，画質(圧縮)モードは BASIC (1/20 圧縮)で撮影する。これに対し て $\mathrm{EOS} \cdot \operatorname{DCS} 3$ は夜間, 室内のスポ ーツなど，暗い環境下で高速シャッ夕 で撮影したい場合に使用している。

1997 年 10 月, ディジタルカメラで の取材件数をまとめた(図 6)。総取材 件数は 64 件, 写真部への取材現場か らの送稿枚数は 238 枚だった。ただ し，ディジタルカメラを持ち出したも のの取材には至らなかった件数を含め れば，取材件数はこの 3 倍近くになる と思われる。10日前後の送稿枚数が 突出しているのは, パリの世界柔道選 手権での枚数が多いため。この取材は ディジタルカメラのみで行った。ま た，1日は J リーグの優勝決定戦があ った。

\section{2 使用上の問題点}

通常のカメラと同じように使えると いっても，ディジタルカメラならでは の問題は大きい。撮影にあたっての問 題点をあげてみよう。

（1）シャッタボタンを押してから シャッタが落ちるまでに若干の

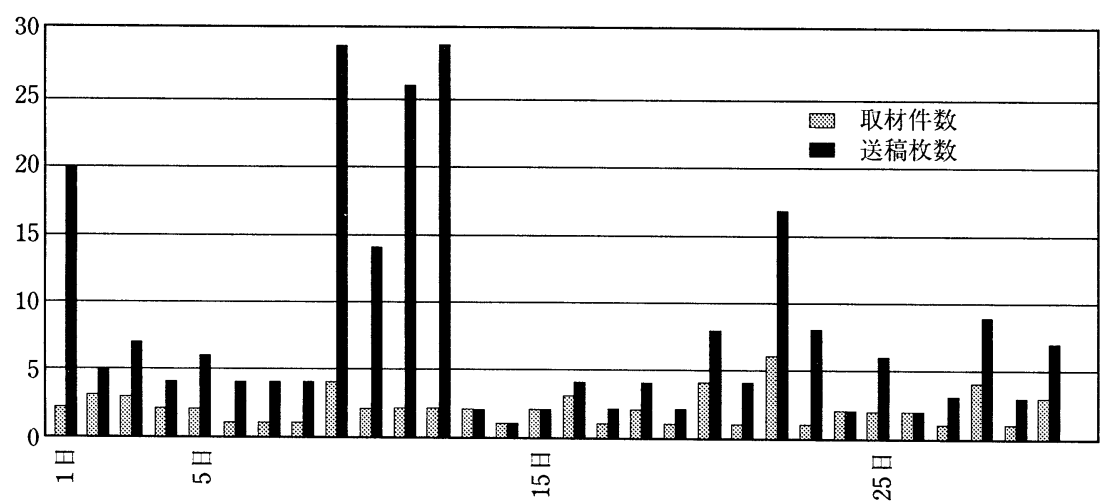

10 月全体の取材件数は 64 件，送稿枚数は 238 枚だった。

図 6 ディジタルカメラ送稿枚数（東京本社写真部 1997 年 10 月分） 
タイムラグがある。CCDに通 電するために仕方がないかもし れないが。

（2）縮小光学系を採用しているた め, すべてのレンズの開放 F 値が 6.7 になってしまう。スポ ーツなどでは高速シャッ夕を切 るために，アンダー承知で撮影 しなければならない。

（3）同上の理由により，一部のレ ンズで画像の周辺部にケラレが 生じ，画面四隅が暗くなる。使 えるレンズにかなり制限があ る. 使用頻度が高い広角系で は, 20〜35 mm ズームレンズ しか使えない。

（4）縮小光学系を採用していない 機種では CCD の面積が小さい ため，実際に写る範囲がファイ ンダよりかなり小さくなってし まう。そのため，実効焦点距離 が 1.7 倍になり, 広角系では $17 \mathrm{~mm}$ レンズでも $28 \mathrm{~mm}$ 相当 となり, 接近取材にはかなり弱 くなる。

（5）適正露光がベストだが，リバ ーサルフィルムと同じように， 露光オーバーよりもアンダーで 撮影する必要がある。

(6) 画素数が $1280 \times 1000$ ピクセ ル程度と少なめなので, トリミ ングすると画質が劣化する。で きるだけ画面いっぱいで撮影し なければならない。
（7）撮影した画像はネガフィルム のような一覧性がない. パソコ ン上でのコマ選択は難しいた め, 撮影枚数はできるだけ減ら すようにする。

（8）電源が長時間保たない.いず れの機種も電源は乾電池などの どこでも手に入るものではない ため, バッテリーがなくなると お手上げだ。

\section{3 画像の評価}

東京本社での使用に基づき，画像の 問題点をまとめた。

（1）晴天時の屋外取材ではかなり 良い発色が得られるものの, 室 内のミックス光線やストロボ光 での撮影では色バランスが崩れ ることが多い(図 7)。

〔図 7〜図 10 は 17 ページに揭載〕

（2）開放 F 值が 6.7 の機種では, 暗い被写体では ISO 3200 でも アンダーになる。レベルを強制 的に補正するとノイズが目立つ ようになる(図 8)。また, 対応 レンズ以外では画面の周辺部が 黒く落ちてしまう(図 9).

(3) 読込み時にホワイトバランス をとらなければならない機種で は, バランスが狂った画像が生 成されるおそれがある。細かい パターンのところでかなり強く 虹色の擬似信号が発生する(図 10)。画像ソフトでかなり補正 することが可能だが，完全には
除去できない。また，全般的に 色の鮮やかさが足りない.

この章の作例は特に条件の悪い画像 を探して使った。いつもこういう画像 になるわけではないことをお断りして おく。

\section{4 画像の電送}

新聞社にとっていちばんの課題は, 撮影したデータをいかに速く本社へ送 るかだ．時間が切迫しているからディ ジタルカメラを使うので, この過程で 時間がかかっていては意味がない。朝 日新聞社では通常の取材では写真部員 自身が電送を行っている。

送信から紙面化までの流れを図 11 に示す。朝日新聞社の場合, 他社と異 なり写真部での受信がメインになって いる。これは, 動きの遅かった社内の システム構築に先だって, 写真部が機 動的にディジタルカメラ導入を行った からに他ならない。この方式はそれな りにメリットがあるため，今後も残る だろう。

\section{（1）送信機材}

パソコンは各自が会社から貸与され ているため，そのまま電送用に利用で きる。市販の通信ソフト, 画像ビュー アと写真部自作ソフトを組合せて使用 している。送信は写真部に設置された 受信パソコンへ原画像のまま送るか, 制作技術部電送室へ電送する。

写真部に送信する場合のみ, 富士フ イルムのハンディトランスミッタ HT 300 などを使用する場合もある.

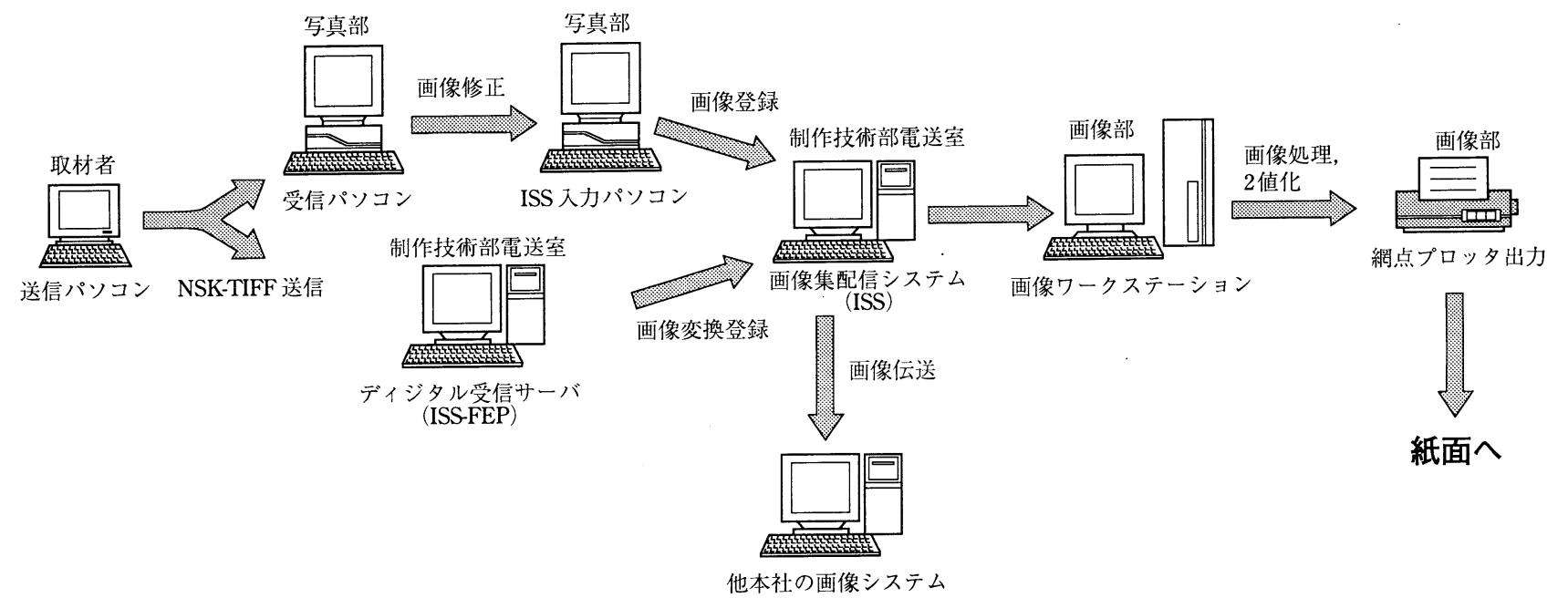

図 11 ディジタルカメラの画像の流れ 
小型軽量で, 通信プログラムを $\mathrm{ROM}$ 化して搭載しているので, 電源 ON ですぐ送信できるのが利点だ。

\section{（2）使用回線}

事件などの現場から伝送する場合， 携帯電話が圧倒的に多い。現場そのも のから送信できるのが強みだ。携带電 話も使えない山中の現場（昨年末の長 野県小谷村の土砂崩れ現場など）では 衛星携帯電話が活躍する. スポーツな どの取材では, 記者席から公衆回線で 伝送することも多い.この方が高速で 伝送できるからだ。

最近では, PIAFS 対応のPHSも かなり利用している. 回線品質はへた な公衆回線よりもはるかに安定してい る。また，国外ではノキアなどの GSM 電話(ヨーロッパ, 東南アジア などで使用可能)やインマルサットミ 二 $\mathrm{M}$ 衛星電話も利用している.

(3) 通信方式

通常は無手順通信でZモデムプロ トコルでの伝送を行う(いわゆるパソ コン通信)。インターネットによる FTP 転送は ISDN 回線でルー夕を使 用した場合に限られる。PPP は, セ キュリティの問題から朝日新聞社では 現在のところ使用していない.

\section{（4）送信画像}

写真部へ電送する場合, JPEG の原 画像をそのまま, EOS・DCS 3 など 固有フォーマットのファイルを生成す る電子カメラでは, JPEG に変換して 送信している。

制作技術部電送室のディジタル受信 サーバ(ISS-FEP)へ送信する際には, NSK-TIFF フォーマットに変換して 電送しなければならない. NSKTIFF は日本新聞協会が策定した共通 画像フォーマットで, 写真説明などの 新聞製作に必要なデー夕を画像に含め て送信できる。

（5）送信先

現在は写真部のパソコンへ送信する のがほとんど．写真部であらかじめ色 調, 明るさなどを整えてから，画像集 配信システム (ISS)へFTPで出稿す る、また，受信状況を写真部でモニ夕 できるのが利点でもある。

制作技術部電送室へ送信すると,シ
ステムが画像情報を解析して画像集配 信システムへ自動的に登録する。

\section{5 紙面制作}

紙面に掲載するために，まず画像を 東京, 大阪, 西部 (九州), 名古屋の四 本社間で相互に配信する画像集配信シ ステム(ISS)に登録しなければならな い.

ISS 登録後, その画像は画像部のイ メージワークステーション(IWS)上 に呼び出すことができる．このIWS 上で画像の色修正を行い，2 值(網点) 化を行ってはじめて印刷できる画像が 生成される。

かつて, プリントした写真を画像部 のドラムスキャナで読込み, 色分解し ていた。電送写真も, CMYK で分版 された受信印画紙をスキャナで読込ん でからで 2 值化し, カラー写真を作成 していた. ISS はアトランタ五輪を機 に運用を開始したもので, ディジタル カメラの画像をこのISS システムへ 直接入力することで, 製版を含む紙面 制作工程に大幅な時間短縮をもたらし た。关机まではディジタルカメラの画 像をピクトログラフィで出力し, 画像 部でスキャンして製版していたのが， この過程すべてが必要なくなったわけ だ。

\section{6 ディジタル画像の処理}

IWS は東京本社に 6 台あり, これ だけで分解版が持ち込まれる広告写真 以外，写真すべてをまかなっている. このワークステーションは, カラース ライドとプリントしかなかった 1990 年に導入されたもので, ディジタル写 真に対応する機能は持っていない. 紙 焼き写真は暗部の濃度が低いが，ディ ジタルデータは純黒まで達する濃度分 布を持っている。ディジタル化当初は 今までと同一の処理を行うと真っ黒な 写真になってしまうなど，かなりトラ ブルが発生したが, 色変換テーブルの 見直しなどで問題はなくなっている。

画像処理上の問題点は, 色かぶりと 中間調の濁りの補正だ。ディジタルカ メラでは厳密なホワイトバランスがと れないため, ぞうしても色が偏ってし まう傾向がある．プリントした完成原 稿を微調整するために作られたワーク
ステーションなので, 色の偏りを大幅 に補正するといった機能がない，その ため, 微調整を何回も繰り返して行わ なければならない. パソコン上の画像 ソフトならば 10 秒程度で終わる処理 を，何分もかけて行う必要がある。

また, 中間調で色が濁る傾向も強い が, トーンカーブ全体をいじる機能も ないため, この場合も複数回処理を繰 り返す必要がある。パソコンの画像り フトでトーンカーブを修正すれば，こ れも簡単に補正できるものだ。

いずれの場合もパソコンで画像を修 正した方が後の画像部での処理が早く 終わるため, 受信した画像を写真部で 補正して, かつての「完成プリント」 に代わる「完成ディジタル画像」とし てシステムに再入力することも多い. こうした問題はディジタル画像に対応 した新しい画像処理ワークステーショ ンが登場するか, より完璧な色再現性 を備えたディジタルカメラが登場する まで解決しないだろう。

\section{5. 実際の取材例}

いままで，速報性では新聞はとうて いテレビにかなわなかった。しかし， ディジタルカメラの登場により, 突発 事件などの局面では新聞がテレビをし のぐこともできるようになってきた． いくつかの取材例をあげよう.

(1) アトランタ五輪で女子マラy ンの有森選手の銅メダルのゴー ルイン, 閉会式の旗手をつとめ た有森選手など, いくつかのシ ーンは朝日新聞だけが早版（一 番締め切りが早い新聞. 遠隔地 へ配達される) からカラ一写真 を揭載することができた（図 12).アシスタントがメモリー カードを撮影場所から記者席ま で全力疾走で運ぶという「原始 的」な方法をとったが，それで も撮影後わずか 10 分で本社の システムまで到着した。

（2） 1997 年 3 月 12 日に起きた動 力炉・核燃料開発事業団東海事 業所の爆発事故で, 午前 0 時に 撮影されたディジタルカメラの カラー航空写真を最終版一面に 


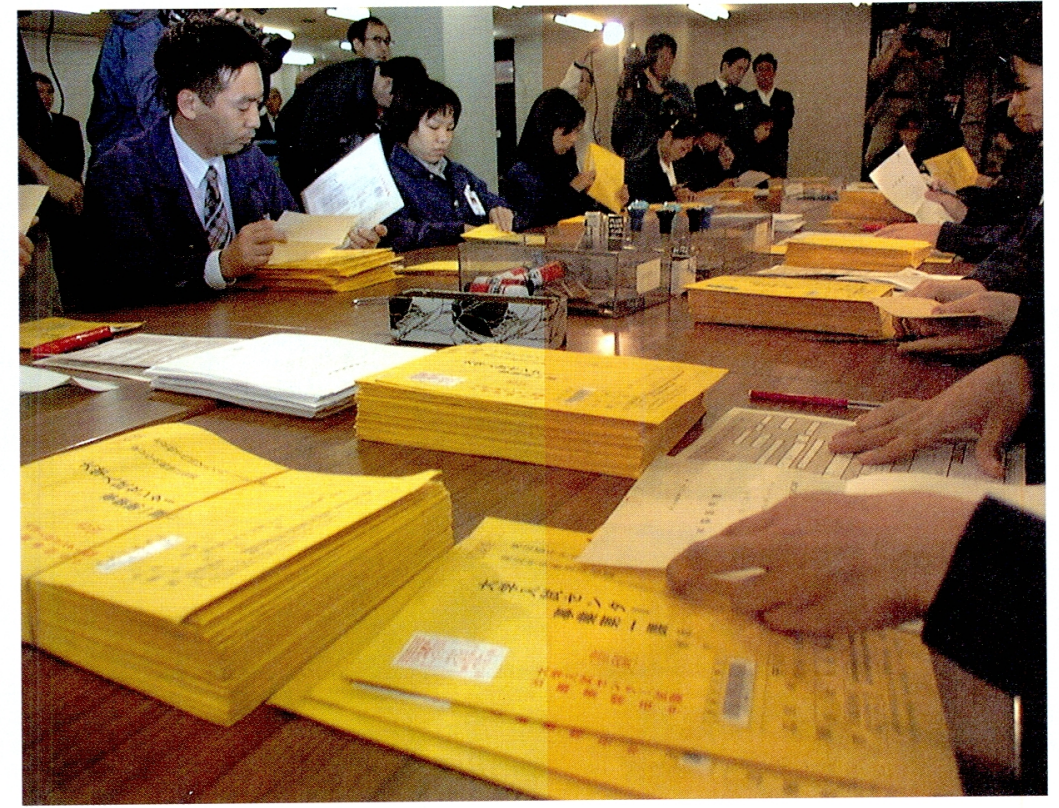

図 7 色かぶりの例（左半分は補正した画像）

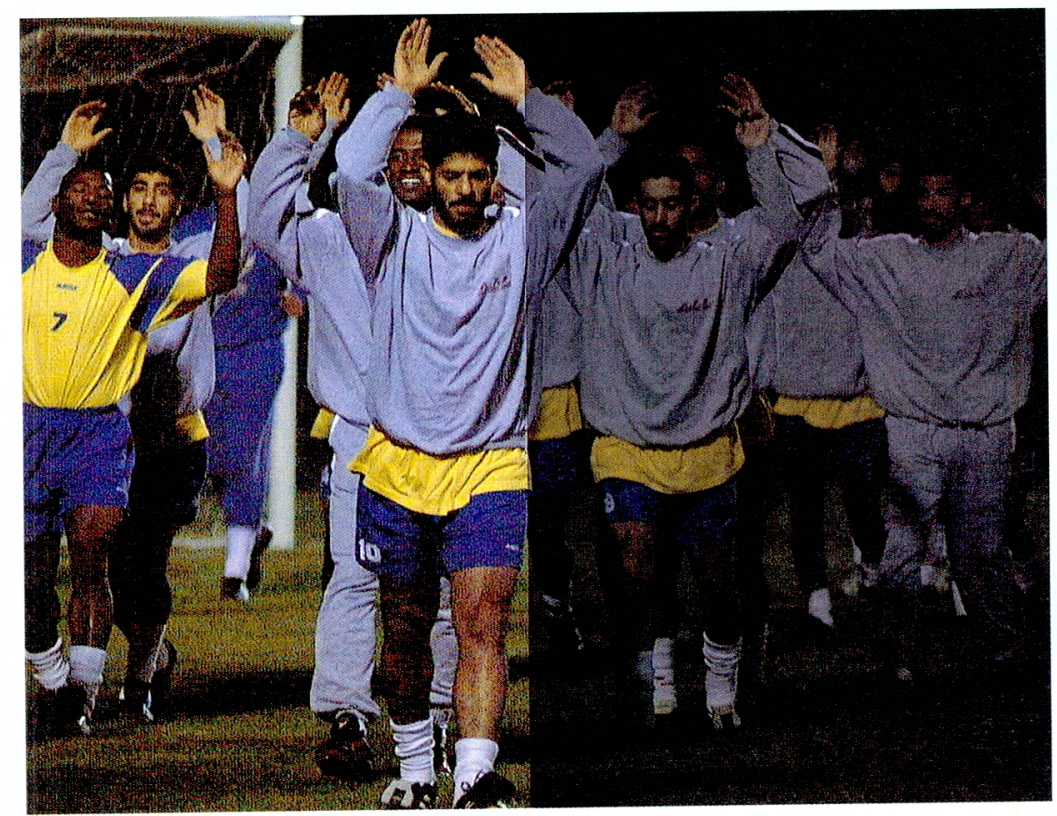

図８露出アンダーな画像（左半分は補正後, 暗部にノイズが目立つ）

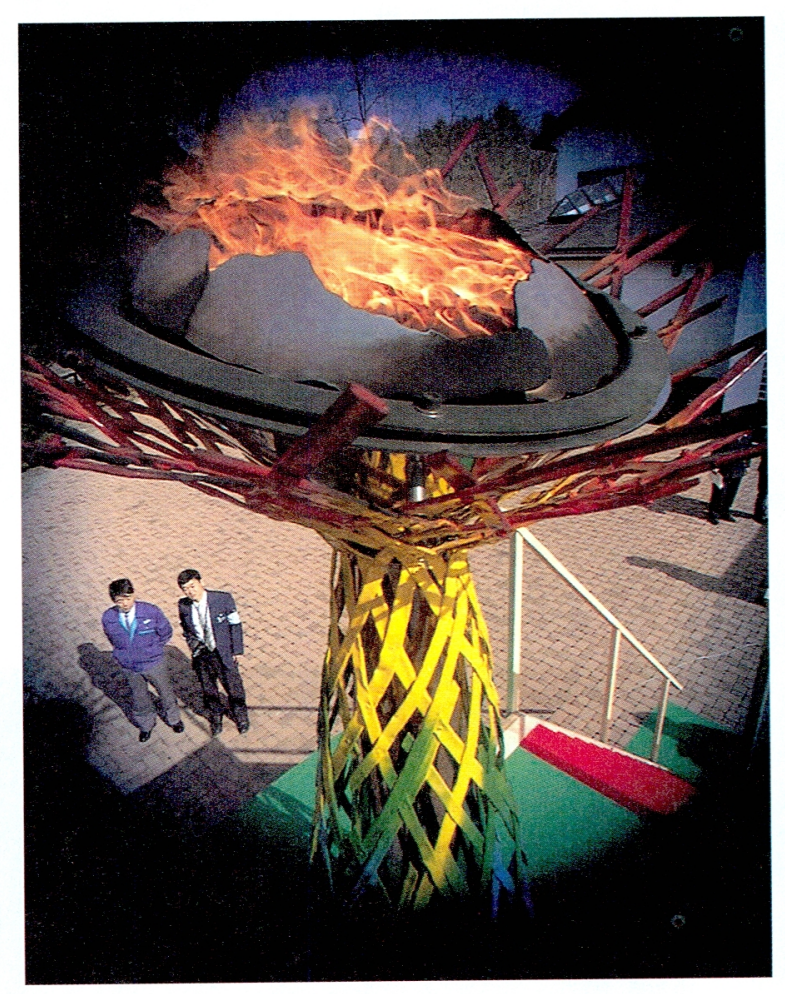

図 9 周辺部が黒くなった画像（20 mm レンズで撮影）

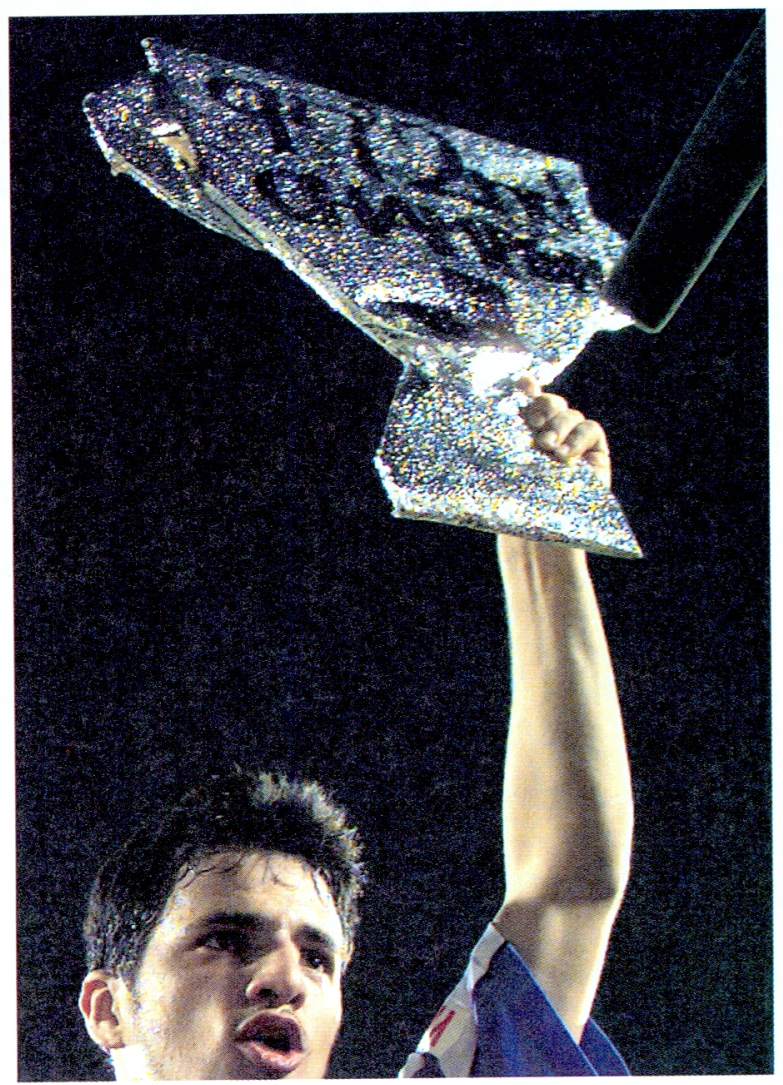

(17) 135 


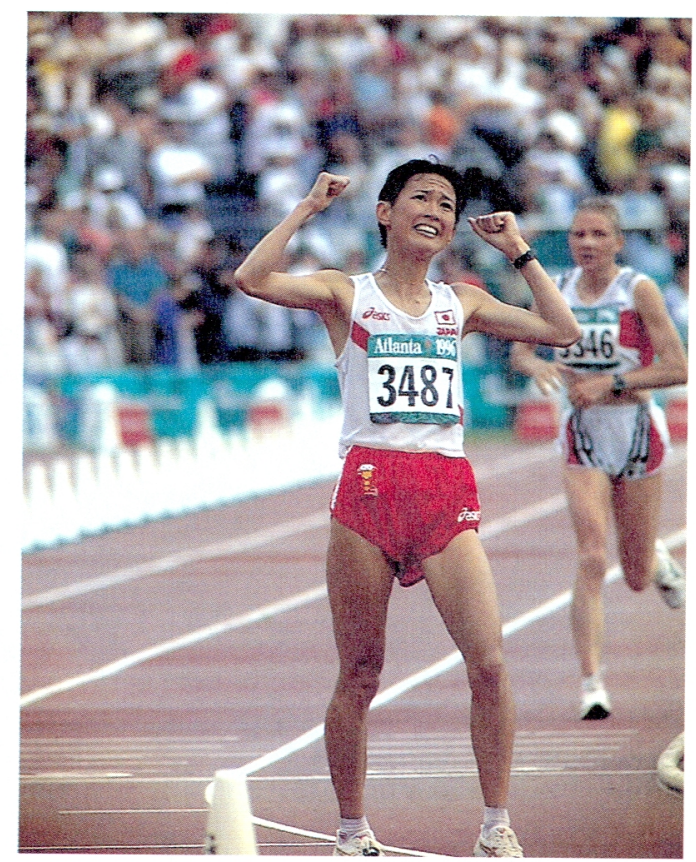

図 12 アトランタ五輪女子マラソンで銅メダルの有森

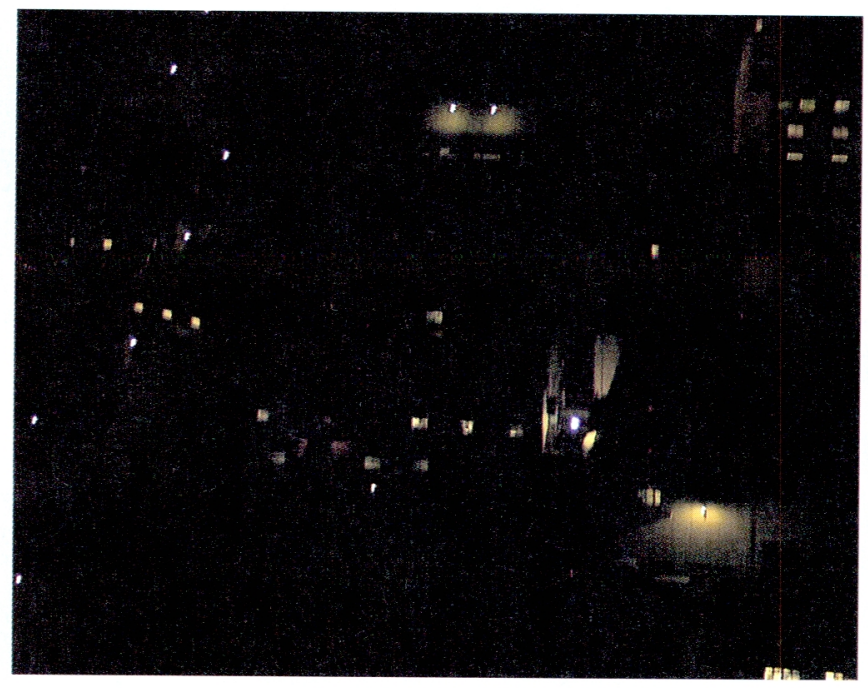

図 13 動力炉・核燃料開発事業団の爆発事故（原画像）(街灯，空 の明かりしか見えない

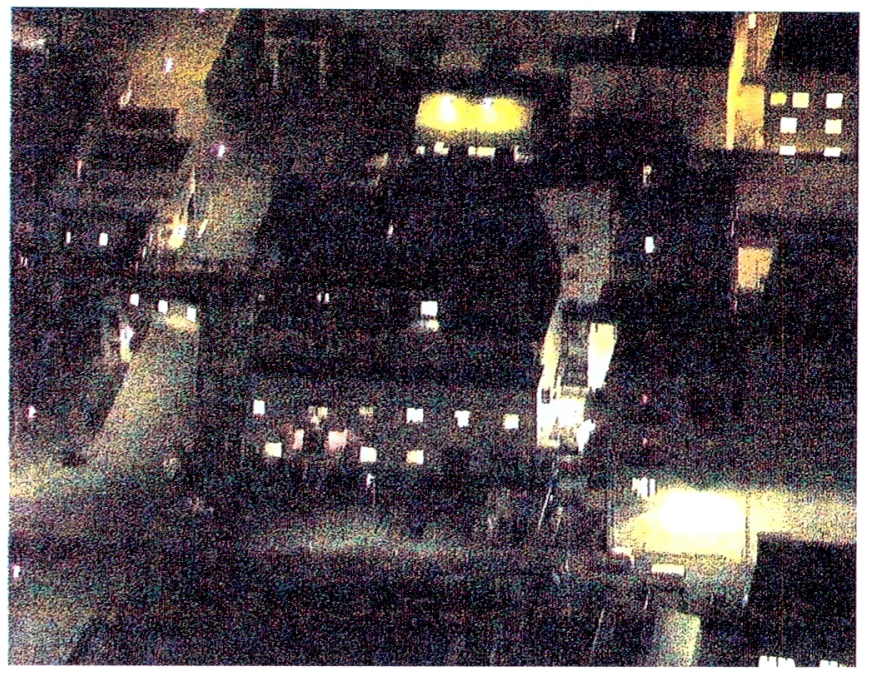

図 14 ぎりぎりまで画像のレベルを補正した（中央に爆発したアス ファルト固化処理施設が見えてきた)

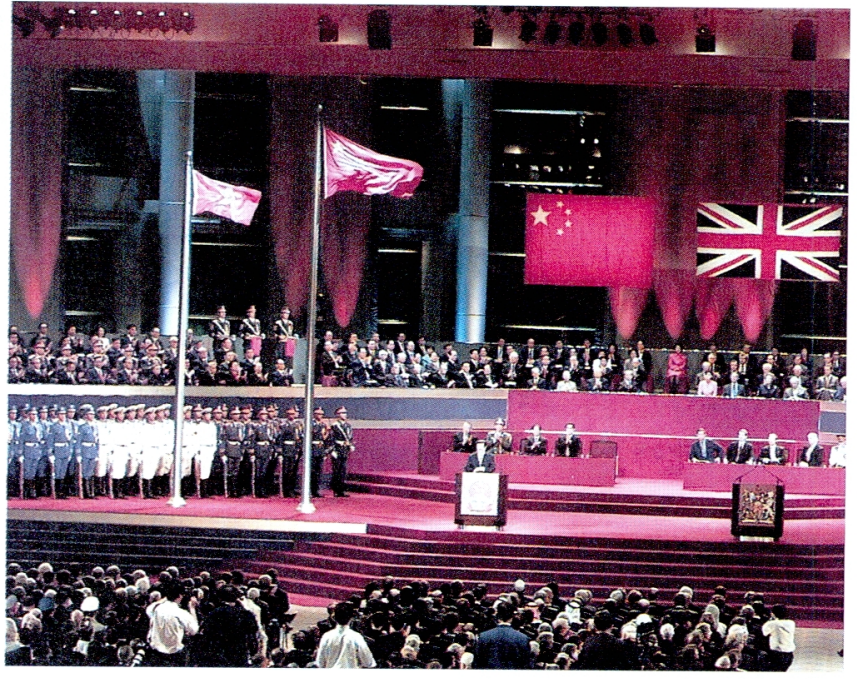

図 15 香港の返還式典（中国国旗が揚がった瞬間）

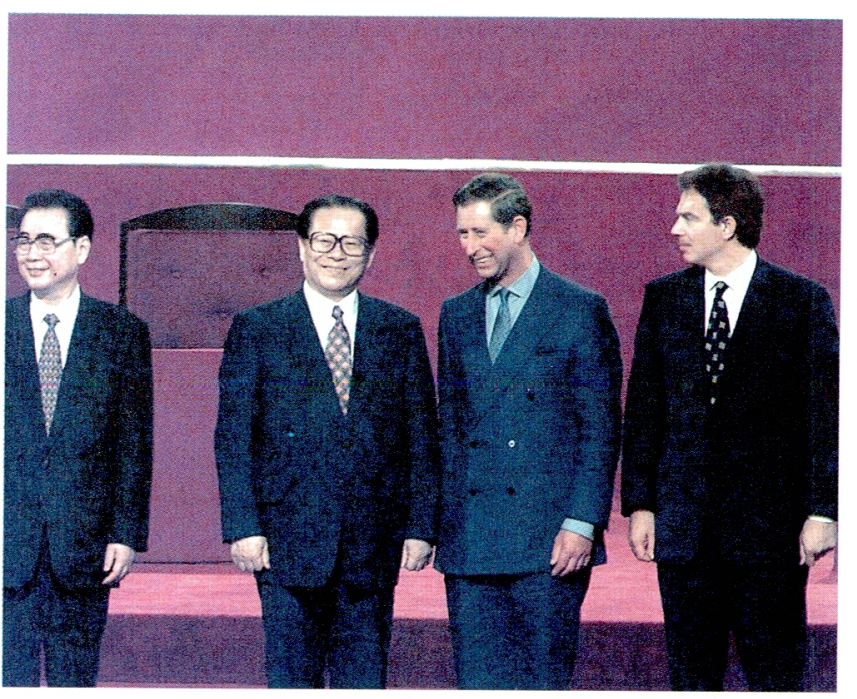

図 16 香港返還式典後，談笑寸る中英首脳

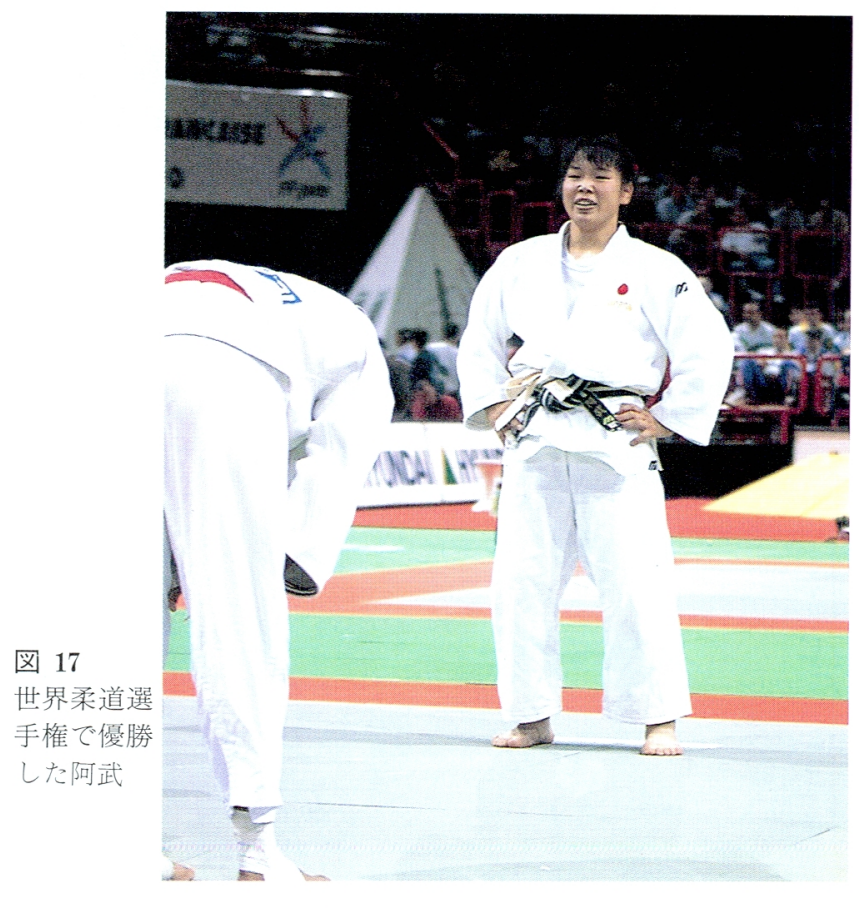

映像情報メディア学会誌Vol. 52, No. 2（1998） 
掲載した. 午前 0 時 45 分に羽 田空港に着陸, 直ちに電話で画 像を伝送，写真部で画像修正を 行ったのち, 午前 0 時 55 分に 画像集配信システムへ登録され た. 従来の銀塩写真であれば, 午前 0 時すぎに電送を開始しな ければ間に合わなかっただろ う。原画はかなりのアンダーだ った(図13)が, 画像のレベル を補正することにより，ノイズ まみれだが，なんとか使える画 像が得られた(図 14).

（3） 1997 年 7 月 1 日午前 0 時 （日本時間午前 1 時）に行われ た中国，英国の香港返還式典 で，ディジタルカメラにより一 面, 三面に 2 枚のカラー写真を 揭載した(図 15, 図 16)。午前 0 時以後の式典カラー写真を 2 枚掲載できたのは, 東京の各新 聞社の中では朝日新聞社だけだ った．式典現場で撮影したディ ジタルカメラ画像を, ディジタ ル携帯電話を利用してパソコン で直接写真部へ電送した効果が 大きかった。

(4) 10 月9日からパリで行われ た世界柔道選手権では, 決勝が 日本時間午前 1 時近くに始まる ため，銀塩カメラを使わず，す ベてディジタルカメラで取材を 行った(図 17). 予選の写真を 早版用としてスタンドの記者席 から電送した後, 準決勝, 決勝 は競技場の畳の横から試合が終 わると同時にパソコンに接続し た携帯電話で電送を開始した。 日本勢が活躍した大会だったこ ともあり, 最終版の紙面では各 階級決勝の写真が紙面を飾っ た。

\section{6. 画像の保存}

電子カメラで撮影した画像をどう保 存するかは, いちばん頭の痛い問題
だ．紙面で再利用する場合には電子デ ータのままで使用できる点はいい。画 像をとりあえず光磁気ディスクに保存 するにしても，コンピュータがないと 画像表示できず, ネガフィルムのよう な一覧性に欠ける。またフォトサービ ス部門から全紙焼き付けの依頼がきた 場合でも，プリントができない。媒体 自体も長期保存には耐えず，将来的に 現在のディスクが読めるドライブが供 給され続けるかどうかは未知数だ。か つての 5 インチ, 8 インチフロッピー ディスクのように消え去ってしまわな いという保障はない.

写真部では, 受信したディジタルカ メラの画像を光磁気ディスクに保存す るのと同時に, フィルムレコーダで $35 \mathrm{~mm}$ フイルムに出力することにし ている。このフィルムを通常のネガフ イルムと同様に保存する．画質は原画 より劣化するかも知れないが, 複数の 保存先があることは悪いことではな い.

また，よくある「別のカットの写真 はないか？」という注文に応えるのは 容易ではない。通常使用するカットだ けを電送したら，すぐにメモリーカー ドを初期化, 再利用しているため, 「別カット」は基本的に存在しないか らだ。使ったカット以外はいらない, と考えれば楽だが，そうもいかないだ ろう。取材現場で, 撮影デー夕を簡単 に安く保存できる方法はないかどうか 思案しているところだ。

\section{7. 電子カメラの今後}

本稿では写真部が使っているプロ向 けディジタルカメラのみを取り上げ た。それ以外に忘れてはならないの が, 廉価版高画質ディジタルカメラに よる，支局など全国通信網のカメラの ディジタル化だ。朝日新聞社には海外 を含めて約 800 人が各地で取材活動を 行っており，これらをディジタル化す れば紙面の質は大きく向上する．現在 各地の支局でテストを行っており, 数
年以内に全国へディジタルカメラを展 開するべく計画を練っているところ だ。

1996 年のアトランタ五輪以降, 新 聞社各社は本格的にディジタルカメラ を導入し始めた。長野五輪へ向けての 1997 年, 通常の仕事へもディジタル カメラが進出してきた. 現在は銀塩カ メラと並んで,「当たり前の」カメラ としての地位を固めつつあるといえ る. 1998 年に入ると, 長野五輪が待 っている.アルペン, ジャンプなどの メジャーな競技が午前中に集中するた め, アトランタ五輪以上にディジタル カメラを多用せざるを得ない.ディジ タルカメラがさらに高画質, 高機能化 すれば, 近い将来, 新聞写真では銀塩 写真はきわめて限定された用途（日曜 版などのカラーリバーサル）でしか使 われなくなるかもしれない。

今までの新聞写真は,「写真技術」 の勝負だった。どんなカメラを使おう が, 最終的にはカメラマンの「腕」が 勝敗を決めた.ディジタルカメラの場 合, どのカメラを使ってどう電送する かも大きな要因になる.いくらいい写 真を撮っても，締め切りに間に合わな ければしょうがないし, 画質はカメラ しだい.カメラマンは写真さえ撮れれ ばいいという時代はすでに終わり，二 ュース感覚に加えて, 画像処理, デー 夕伝送を含めたコンピュータ技術も要 求される時代になってきたといえよ う. (1997 年11月 5 日受付)

(注) 本稿では, いわゆる「伝送」（デ 一夕伝送)のうち,ディジタルカ メラの画像を含む写真画像を伝送 することを特に「電送」(写真電 送)と表記した。

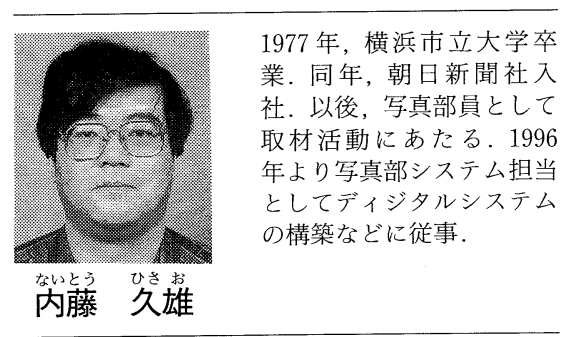

